\title{
Pembuatan Modul Rekomendasi pada OpenCart Menggunakan Metode Item-Based Collaborative Filtering
}

\section{Making Recommender Module in OpenCart Using Item-Based Collaborative Filtering Method}

KIRANA NURYUNITA*, YANI NURHADRYANI

\begin{abstract}
Abstrak
Penelitian ini bertujuan menambahkan modul rekomendasi pada content management system Opencart. Salah satu pendekatan dalam rekomendasi adalah item-based collaborative filtering. Metode item-based collaborative filtering dapat mengurangi waktu eksekusi perhitungan. Metode item-based collaborative filtering pada penelitian ini menggunakan perhitungan adjusted cosine similarity untuk menghitung nilai kemiripan antarbuku dan weighted sum untuk menghitung nilai prediksi rate buku. Untuk mendapatkan rekomendasi, pengguna harus melakukan login dan memberikan rate pada buku. Berdasarkan rate pengguna, nilai kemiripan dihitung menggunakan adjusted cosine similarity. Berdasarkan kemiripan antarbuku, nilai prediksi rate buku dicari menggunakan weighted sum. Sebelum buku direkomendasikan kepada pengguna, kategori prediksi buku dicocokkan dengan kategori buku yang telah diberi rate oleh pengguna. Penelitian ini menggunakan 300 buku dan 30 pengguna sebagai data. Dari hasil penelitian, hanya 17 pengguna yang mendapatkan rekomendasi. Pengujian dilakukan dengan menganalisis waktu eksekusi dan keakuratan rekomendasi. Waktu eksekusi dalam pengujian ini adalah 1.60 detik. Untuk menghitung keakuratan rekomendasi, penelitian ini menggunakan mean absolute error dengan hasil perhitungan 0.15 .
\end{abstract}

Kata kunci: e-commerce, item-based collaborative filtering, recommender system.

\begin{abstract}
This research aims to add recommender module in OpenCart content management system. One of the recommender method is item-based collaborative filtering. Item-based collaborative filtering method can reduce execution time of calculation. The method of item-based collaborative filtering in this study uses adjusted cosine similarity to calculate the similarity between the books and uses weighted sum method to calculate the books rate prediction. To get the recommendation, user have to login and give ratings to the books first. Based on user's rate, adjusted cosine similarity calculate the similarity between books. Based on the similarities between books, weighted sum method calculate the books rate prediction. Before a book is recommended to the user, type of the book from prediction are then matched with the book type rated by a user. This research uses 300 books and 30 users as the data. From the result, only 17 users will get recommendations based on the calculation from adjusted cosine similarity and weighted sum method. Testing is done by analyzing execution time and calculation error. The result of execution time is 1.60 seconds. To count calculation error, this research use mean absolute error and the result of calculation is 0.15 .
\end{abstract}

Keywords: e-commerce, item-based collaborative filtering,recommender system.

\section{PENDAHULUAN}

Informasi dengan berbagai macam kriteria terdapat di internet, salah satunya adalah informasi tentang penjualan produk dan jasa secara online atau biasa disebut e-commerce. 
Faktor yang dapat mendorong penjualan dalam e-commerce ialah menyangkut personalisasi dari pembeli di internet. Sistem rekomendasi merupakan salah satu bentuk dari personalisasi website. Sistem rekomendasi merupakan model penyelesaian masalah yang menerapkan teknik-teknik tertentu pada pembuatan rekomendasi untuk pemilihan suatu informasi, produk, dan jasa (Goldberg et al. 2001).

Terdapat dua pendekatan dalam mengembangkan sebuah sistem rekomendasi, yaitu content-based dan collaborative filtering (Balabanovic dan Shoham 1997). Pendekatan content-based menyediakan rekomendasi dengan cara membandingkan representasi konten yang terkandung dalam sebuah produk dengan representasi konten yang diinginkan pengguna dengan membangun user thematic profile, sedangkan pendekatan collaborative filtering bekerja dengan cara mempelajari masukan rate dari pengguna pada kumpulan produk, mengenali kesamaan berdasarkan masukan pengguna, dan menghasilkan rekomendasi baru (Candillier et al. 2007). Rekomendasi berdasarkan pendekatan collaborative filtering merupakan pendekatan yang paling banyak digunakan untuk membangun sebuah sistem rekomendasi (Burke 2002). Teknik collaborative filtering terbagi menjadi dua, yaitu userbased collaborative filtering dan item-based collaborative filtering (Karypis 2001). Pada user-based collaborative filtering, sistem mencari sejumlah pengguna yang memiliki korelasi tinggi, sedangkan pada item-based collaborative filtering, sistem mencari sejumlah produk yang memiliki korelasi tinggi. User-based collaborative filtering memerlukan data pengguna. Pengguna lama dapat mengubah pola perilaku mereka dan pengguna baru dapat memasuki sistem setiap saat. Banyaknya data pengguna membutuhkan proses yang cukup lama untuk menghasilkan rekomendasi. Item-based collaborative filtering memerlukan data koleksi produk yang relatif lebih sedikit dibanding data pengguna bersifat statis sehingga memungkinkan pengurangan perhitungan (Sarwar et al. 2001).

Pembuatan situs e-commerce dapat dilakukan dengan menggunakan content management system (CMS). Salah satu CMS yang populer di masyarakat adalah OpenCart (Masalov 2007). OpenCart telah memiliki beberapa modul seperti account, affiliate, banner, bestsellers, carousel, category, featured, googletalk, information, latest, slideshow, specials, store, dan welcome. Namun, OpenCart belum memiliki modul yang dapat menghasilkan rekomendasi untuk pengguna.

Penelitian ini menambahkan modul baru, yaitu modul rekomendasi pada CMS OpenCart. Modul rekomendasi dikembangkan menggunakan metode item-based collaborative filtering. Metode item-based collaborative filtering pada penelitian ini menggunakan perhitungan adjusted cosine similarity untuk menghitung nilai kemiripan antarproduk dan weighted sum untuk menghitung nilai prediksi rate produk.

\section{METODE PENELITIAN}

Metode yang dilakukan pada penelitian ini terdiri atas beberapa tahap, yaitu analisis kebutuhan, perancangan sistem, implementasi item-based collaborative filtering, dan pengujian item-based collaborative filtering.

\section{Analisis Kebutuhan}

Analisis meliputi analisis kebutuhan data dan analisis kebutuhan fungsi. Analisis kebutuhan data adalah analisis CMS yang cukup populer di masyarakat Indonesia. CMS dicari berdasarkan Indonesia traffic rank tertinggi melalui situs alexa.com. Data buku yang digunakan pada penelitian ini berjumlah 300 buku yang diambil dari situs bukukita.com. Data pengguna pada penelitian ini berjumlah 30 pengguna mahasiswa IPB yang memberi rate untuk minimal 5 buku pada sistem. Tahapan pada analisis fungsi terdiri atas pemberian rate oleh pengguna, perhitungan rata-rata rate pengguna, perhitungan nilai kemiripan produk menggunakan adjusted cosine similarity, perhitungan prediksi produk menggunakan weighted 
sum, dan pencocokan kategori produk prediksi dengan kategori produk yang diberi rate oleh pengguna.

\section{Perancangan Sistem dan Implementasi Item-Based Collaborative Filtering}

Perancangan sistem terdiri atas perancangan database dan perancangan antarmuka. Pada tahap implementasi, adjusted cosine similarity dan weighted sum diterjemahkan ke dalam sistem dan ditambahkan pada modul untuk menghasilkan sebuah rekomendasi. Persamaan adjusted cosine similarity digunakan untuk menghitung nilai kemiripan antarproduk. Persamaan adjusted cosine similarity adalah sebagai berikut (Karypis 2001):

$$
\operatorname{sim}_{(i, j)}=\frac{\sum_{u \in U}\left(r_{u, i}-\bar{r}_{u}\right)\left(r_{u, j}-\bar{r}_{u}\right)}{\sqrt{\sum_{u \in U}\left(r_{u, i}-\bar{r}_{u}\right)^{2}} \sqrt{\sum_{u \in U}\left(r_{u, j}-\bar{r}_{u}\right)^{2}}}
$$

dengan:

$\operatorname{sim}_{(i, j)}$ adalah nilai kemiripan antara produk $i$ dan $\operatorname{produk} j$,

$u \in U$ adalah himpunan pengguna u yang memberikan rate pada produk $i$ dan produk $j$,

$r_{u, \mathrm{i}}$ adalah rating pengguna $u$ pada produk $i$,

$r_{u, j}$ adalah rating pengguna $u$ pada produk $j$,

$\overline{r_{u}}$ adalah rata-rata rating pengguna $u$.

Dalam menghitung nilai kemiripan, nilai yang dihasilkan oleh persamaan adjusted-cosine similarity berkisar antara +1.0 dan -1.0 . Informasi korelasi yang diketahui berdasarkan pada nilai kemiripan menurut Marmanis dan Babenko (2009): nilai kemiripan 0: kedua produk tidak berkorelasi (independen), Nilai kemiripan mendekati +1.0 : kedua produk berkorelasi tinggi, dan nilai kemiripan mendekati -1.0: kedua produk saling bertolak belakang.

Setelah mendapatkan sekumpulan produk yang sangat mirip, dilakukan proses prediksi yang memperkirakan nilai rate dari pengguna. Prediksi yang diperkirakan adalah produk yang belum pernah diberi rate oleh pengguna. Teknik yang digunakan untuk mendapatkan nilai prediksi adalah dengan persamaan weighted sum (Karypis 2001) berikut:

$$
\mathrm{P}(u, j)=\frac{\sum_{i \in I}\left(\mathrm{R}_{u, i}{ }^{*} \mathrm{~S}_{i, j}\right)}{\sum_{i \in I}\left|\mathrm{~S}_{i, j}\right|}
$$

dengan:

$\mathrm{P}(u, j)$ adalah prediksi untuk pengguna $u$ pada $\operatorname{produk} j$.

$i \in I$ adalah himpunan produk yang mirip dengan produk $j$.

$R_{u, i}$ adalah rate pengguna $u$ pada produk $i$.

$S_{i, j}$ adalah nilai kemiripan antara produk $i$ dan produk $j$.

\section{Pengujian Item-Based Collaborative Filtering}

Pengujian terhadap sistem dilakukan dengan menggunakan mean absolute error (MAE) untuk mengetahui nilai keakuratan dari rekomendasi yang dihasilkan. MAE yang ditunjukkan pada persamaan 3 merupakan persamaan yang digunakan untuk mengukur akurasi sistem dengan membandingkan nilai yang diprediksi dengan nilai yang sebenarnya (Karypis 2001). Persamaan MAE digunakan untuk mengevaluasi kualitas dari sistem dan perhitungan yang paling sering digunakan (Candillier et al. 2007). Semakin kecil nilai MAE yang dihasilkan, prediksi yang dihasilkan semakin baik.

$$
\mathrm{MAE}=\frac{\sum_{i=1}^{N}\left|p_{i}-q_{i}\right|}{N}
$$

dengan:

MAE adalah nilai rata-rata kesalahan hitung. 
$N$ adalah jumlah produk yang dihitung.

$p_{i}$ adalah nilai prediksi produk ke- $i$.

$q_{i}$ adalah nilai rate sebenarnya ke produk $i$.

Pengujian juga dilakukan dengan menghitung waktu eksekusi yang dibutuhkan sistem untuk menghasilkan sebuah rekomendasi. Pengujian dilakukan pada lingkungan pengembangan perangkat keras ProcessorIntel Core 2 Duo $1.6 \mathrm{GHz}$, RAM 2GB, dan Hard drive $120 \mathrm{~GB}$.

\section{HASIL DAN PEMBAHASAN}

\section{Analisis Kebutuhan}

\section{Kebutuhan Data}

Analisis mengenai pemilihan CMS yang dipakai dilakukan dengan situs Alexa. Pemilihan Alexa sebagai tool analisis data website dikarenakan situs ini menyediakan layanan perangkingan secara otomatis untuk seluruh situs di dunia (Saidah 2012). Berdasarkan situs Alexa yang diakses dengan queryopensource shopping cart, lima global traffic rank tertinggi adalah magentocommerce, sitepoint, prestashop, rackspace hosting, dan OpenCart. Dari 5 peringkat berdasarkan global traffic rank tersebut, peringkat berdasarkan Indonesia traffic rank dicari. Situs yang memiliki Indonesia traffic rank tertinggi ialah OpenCart.

Aspek kesuksesan e-commerce menurut $\mathrm{O}^{`} B$ Bien (2006) terdiri atas sembilan aspek dengan 7 aspek merupakan proses yang dilakukan secara online dan 2 aspek lainnya merupakan proses yang dilakukan secara offline. OpenCart telah memiliki 7 aspek online berdasarkan O'Brien (2006), yaitu:

1 Pengendalian akses dan keamanan: terdapat verifikasi bagi pengguna yang login.

2 Manajemen pencarian: terdapat fungsi pencarian yang memudahkan pengguna dalam mencari suatu produk.

3 Manajemen isi: terdapat fungsi untuk memperbaharui maupun menambah produk.

4 Manajemen katalog: terdapat fungsi pembagian produk menjadi kategori-kategori tertentu.

5 Pembayaran: terdapat alur proses belanja sampai verifikasi pembayaran.

6 Pemberitahuan kegiatan: terdapat notifikasi apabila pengguna melakukan suatu proses pada sistem.

7 Pembuatan profil dan personalisasi: terdapat fungsi untuk menyimpan profil pengguna dan history pembelian bagi pengguna yang telah login ke dalam sistem. OpenCart hanya memiliki aspek pembuatan profil. Salah satu cara untuk menciptakan personalisasi ialah dengan adanya sistem rekomendasi.

\section{Kebutuhan Fungsi}

Gambar 1 menunjukkan simulasi rekomendasi yang terjadi pada sistem. Sistem memanfaatkan masukan rate dari pengguna untuk menghasilkan rekomendasi. Pada Gambar 1, pengguna A memberikan rate pada buku 1, pengguna B memberikan rate pada buku 1 dan 2 , pengguna $\mathrm{C}$ memberikan rate pada buku 2 dan 3, dan pengguna $\mathrm{D}$ memberikan rate pada buku 1 dan 3. Berdasarkan masukan rate tersebut, dicari pasangan buku yang memiliki korelasi tinggi atau similar menggunakan adjusted cosine similarity. Pada Gambar 1, buku yang memiliki korelasi tinggi adalah buku 2 dan buku 3. Nilai prediksi rate dari pasangan buku yang memiliki korelasi tinggi dicari menggunakan weighted sum. Kategori prediksi buku lalu dicocokkan dengan kategori buku yang telah diberi rate. Buku 1, 2, dan 3 memiliki kategori yang sama pada Gambar 1. Pengguna yang memiliki rekomendasi adalah pengguna B dengan rekomnedasi buku 3 dan pengguna D dengan rekomendasi buku 2. 


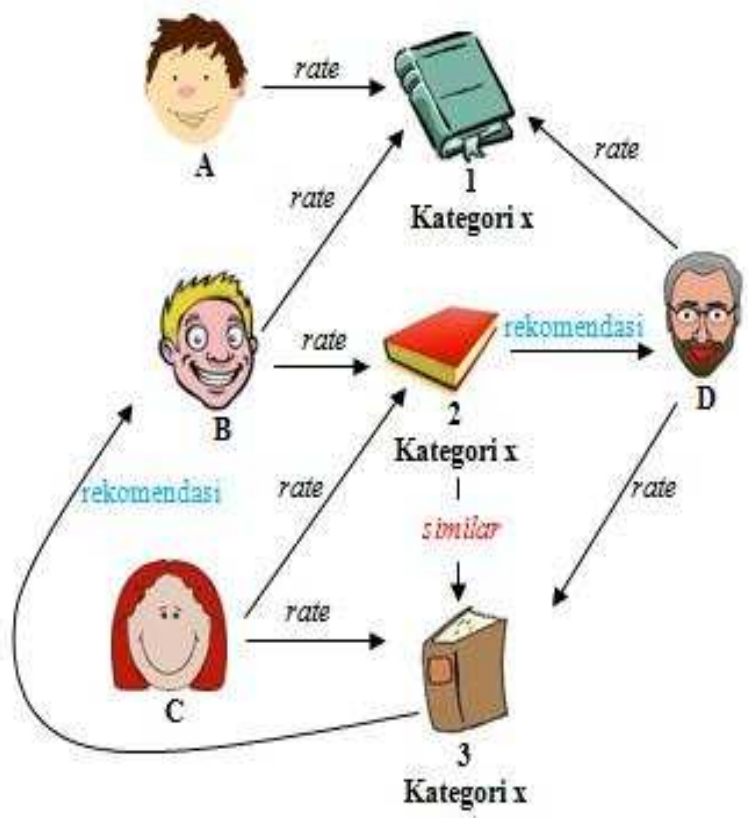

Gambar 1 Simulasi rekomendasi

Pada DFD konteks (Gambar 2) dapat dilihat bahwa pengguna memberi rate pada suatu buku. Rate tersebut lalu diolah oleh sistem untuk mencari buku yang memiliki kemiripan dengan buku yang telah diberi rate sebelumnya. Apabila terdapat buku yang memiliki kemiripan, sistem memberikan rekomendasi buku pada pengguna.

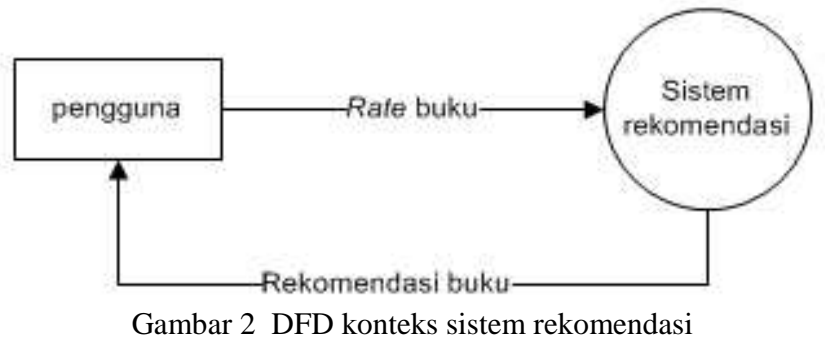

DFD level 1 (Gambar 3) menjelaskan alur rekomendasi. Atribut yang terkait dengan pemberian rate pada produk, yaitu rate, customer_id, dan product_id, disimpan dalam database. Kemudian, sistem menghitung rata-rata rate pengguna dan disimpan dengan atribut average_rating dan customer_id. Setelah rata-rata rate dihitung, sistem menghitung kemiripan antarproduk dan menyimpannya dengan atribut similarity, product_id, dan customer_id. Sistem lalu menghitung nilai prediksi rate produk dan menyimpannya dengan atribut prediction rate, product_id, dan customer_id. Kemudian, kategori produk yang telah diberi rate oleh pengguna dicocokkan dengan kategori produk prediksi. Kategori yang memiliki kesamaan direkomendasikan kepada pengguna.

Berdasarkan pada Gambar 3, simulasi dari proses rekomendasi dibuat. Proses pertama dan kedua dalam menghasilkan rekomendasi adalah mengumpulkan data pengguna yang telah memberi rate pada buku dan menghitung rata-rata rate dari pengguna. Pemberian rate dilakukan oleh pengguna yang telah login. Simulasi data pengguna yang telah memberi rate dapat dilihat pada Tabel 1. Pada tabel, $U$ melambangkan pengguna, $I$ melambangkan buku, dan $\bar{U}$ melambangkan nilai rata-rata rate pengguna.

Proses ketiga ialah menghitung nilai kemiripan antarbuku menggunakan adjusted cosine similarity. Simulasi nilai kemiripan antarbuku dapat dilihat pada Tabel 2, dengan $I$ melambangkan buku. Berdasarkan Tabel 1, terdapat empat pasang buku yang memiliki nilai kemiripan lebih besar dari 0.5 yaitu $\mathrm{I}_{1}$ dengan $\mathrm{I}_{5}, \mathrm{I}_{3}$ dengan $\mathrm{I}_{5}, \mathrm{I}_{3}$ dengan $\mathrm{I}_{6}$, dan $\mathrm{I}_{5}$ dengan $\mathrm{I}_{6}$. 
Proses keempat ialah menghitung nilai prediksi rate buku menggunakan weighted sum. Pasangan buku yang dijadikan rekomendasi adalah pasangan buku yang nilai kemiripannya lebih besar dari 0.5 . Pengguna yang diberikan prediksi rate buku hanya pengguna yang baru memberikan rate pada salah satu buku (Tabel 3), dengan $U$ melambangkan pengguna dan $I$ melambangkan buku.

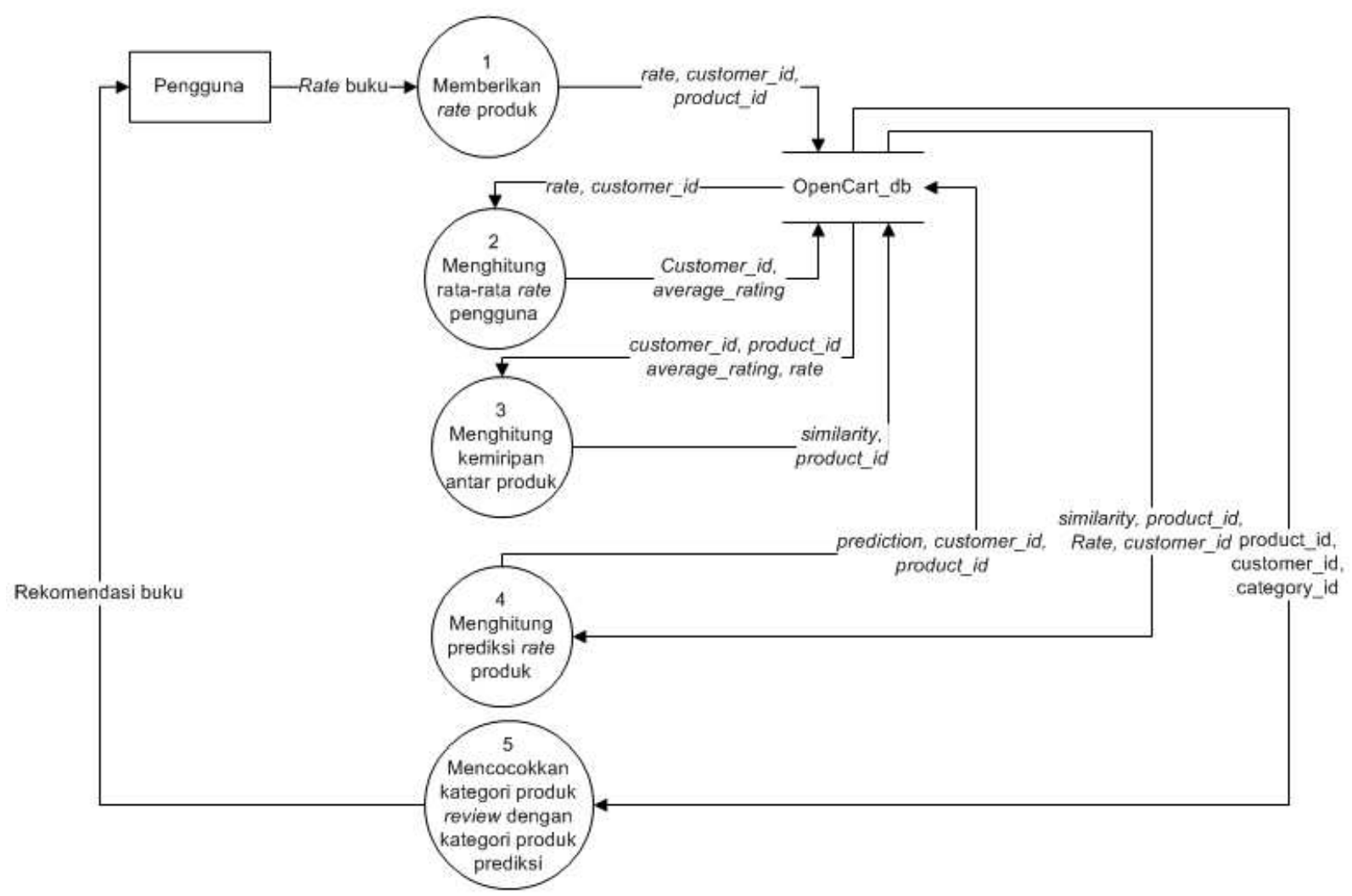

Gambar 3 DFD level 1sistem rekomendasi

Tabel 1 Rate buku dari pengguna

\begin{tabular}{lcccccccc}
\hline Pengguna & $I_{1}$ & $I_{2}$ & $I_{3}$ & $I_{4}$ & $I_{5}$ & $I_{6}$ & $I_{7}$ & $\bar{U}$ \\
\hline$U_{I}$ & 3 & 5 & 3 & - & - & - & 2 & 3.25 \\
$U_{2}$ & 5 & - & - & 2 & 5 & 5 & - & 4.25 \\
$U_{3}$ & 1 & - & 2 & - & - & - & 2 & 1.67 \\
$U_{4}$ & - & - & - & 4 & 5 & 5 & - & 4.67 \\
$U_{5}$ & 4 & 2 & 3 & 3 & 3 & - & - & 3.00 \\
$U_{6}$ & 3 & 4 & - & - & - & 1 & 4 & 3.00 \\
$U_{7}$ & - & - & - & - & - & 4 & 4 & 4.00 \\
$U_{8}$ & - & 5 & 5 & 2 & - & 5 & - & 4.25 \\
$U_{9}$ & - & - & 5 & - & 5 & - & 4 & 4.67 \\
$U_{10}$ & - & 4 & - & - & 5 & - & 3 & 4.00 \\
$U_{11}$ & - & - & - & 2 & 4 & - & 3 & 3.00 \\
$U_{12}$ & - & - & - & 4 & 3 & - & 5 & 4.00 \\
\hline
\end{tabular}

Sebelum prediksi diberikan kepada pengguna, terdapat proses kelima yaitu pencocokan prediksi buku dengan kategori buku yang telah diberi rate oleh pengguna. Apabila kategori buku dari prediksi yang dihasilkan sama dengan kategori buku berdasarkan rate dari pengguna, buku prediksi tersebut direkomendasikan. 
Tabel 2 Nilai kemiripan antarbuku

\begin{tabular}{ccc}
\hline Buku1 & Buku2 & Nilai kemiripan \\
\hline$I_{1}$ & $I_{2}$ & -0.62 \\
$I_{1}$ & $I_{3}$ & -0.31 \\
$I_{1}$ & $I_{4}$ & -0.60 \\
$I_{1}$ & $I_{5}$ & $0.60^{*}$ \\
$I_{1}$ & $I_{6}$ & 0.35 \\
$I_{1}$ & $I_{7}$ & 0.08 \\
$I_{2}$ & $I_{3}$ & 0.07 \\
$I_{2}$ & $I_{4}$ & -0.60 \\
$I_{2}$ & $I_{5}$ & 0.00 \\
$I_{2}$ & $I_{6}$ & -0.54 \\
$I_{2}$ & $I_{7}$ & -0.31 \\
$I_{3}$ & $I_{4}$ & -1.00 \\
$I_{3}$ & $I_{5}$ & $1.00^{*}$ \\
$I_{3}$ & $I_{6}$ & $1.00^{*}$ \\
$I_{3}$ & $I_{7}$ & 0.26 \\
$I_{4}$ & $I_{5}$ & -0.69 \\
$I_{4}$ & $I_{6}$ & -0.99 \\
$I_{4}$ & $I_{7}$ & 0.00 \\
$I_{5}$ & $I_{6}$ & $1.00^{*}$ \\
$I_{5}$ & $I_{7}$ & -0.80 \\
$I_{6}$ & $I_{7}$ & -1.00 \\
\hline
\end{tabular}

*Pasangan buku yang memiliki nilai similarity lebih besar dari 0.5

Tabel 3 Prediksi rate buku

\begin{tabular}{cl}
\hline Pengguna & Prediksi rate buku \\
\hline$U_{I}$ & $\left(I_{5}, 3\right)\left(I_{6}, 3\right)$ \\
$U_{2}$ & $\left(I_{3}, 5\right)$ \\
$U_{3}$ & $\left(I_{5}, 2\right)\left(I_{6}, 2\right)$ \\
$U_{4}$ & $\left(I_{1}, 5\right)\left(I_{3}, 5\right)$ \\
$U_{5}$ & $\left(I_{6}, 3\right)$ \\
$U_{6}$ & $\left(I_{3}, 1\right)\left(I_{5}, 2\right)$ \\
$U_{7}$ & $\left(I_{3}, 4\right)\left(I_{5}, 4\right)$ \\
$U_{8}$ & $\left(I_{5}, 5\right)$ \\
$U_{9}$ & $\left(I_{1}, 5\right)\left(I_{6}, 5\right)$ \\
$U_{10}$ & $\left(I_{1}, 5\right)\left(I_{3}, 5\right)\left(I_{6}, 5\right)$ \\
$U_{11}$ & $\left(I_{1}, 4\right)\left(I_{3}, 4\right)\left(I_{6}, 4\right)$ \\
$U_{12}$ & $\left(I_{1}, 3\right)\left(I_{3}, 3\right)\left(I_{6}, 3\right)$ \\
\hline
\end{tabular}

\section{Perancangan Sistem}

\section{Perancangan Database}

CMS OpenCart yang digunakan telah memiliki database agar sistem dapat berjalan dengan baik. Walaupun OpenCart telah memiliki database yang cukup lengkap, untuk menambahkan modul rekomendasi diperlukan beberapa tambahan tabel. Pada pembahasan pemodelan proses rekomendasi diperlukan empat tabel untuk menyimpan data yang dibutuhkan dalam menghasilkan rekomendasi. Tabel yang dibutuhkan adalah tabel untuk menyimpan nilai rate dari pengguna, tabel untuk menyimpan nilai rata-rata rate dari pengguna, tabel untuk menyimpan nilai kemiripan antarbuku, dan tabel untuk menyimpan prediksi buku (Gambar 4). Tabel yang digunakan untuk menyimpan nilai rate dari pengguna telah ada pada OpenCart, yaitu tabel review. Tabel lainnya tidak terdapat pada OpenCart sehingga ditambahkan ke dalam database. Tabel review_average ditambahkan untuk menyimpan nilai rata-rata rate dari pengguna. Tabel similarity ditambahkan untuk menyimpan nilai kemiripan antarbuku. Tabel prediction ditambahkan untuk menyimpan nilai prediksi buku. 


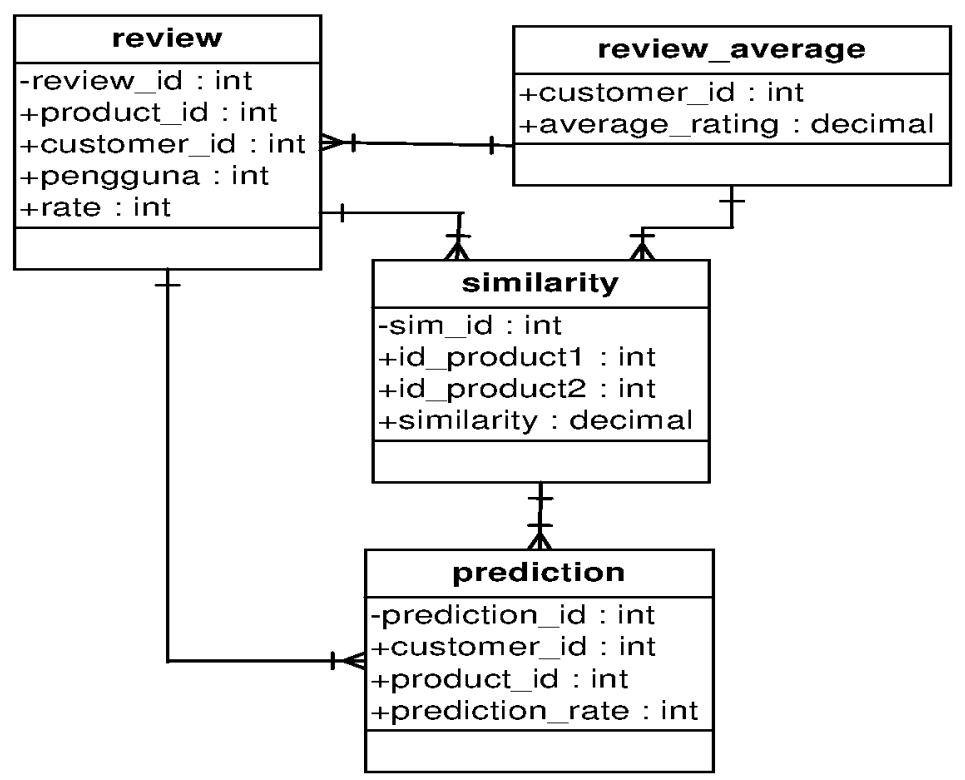

Gambar 4 Entity relationship diagram sistem rekomendasi

Perancangan Antarmuka

Antarmuka pada halaman home ditambah dengan modul baru, yaitu recommended product. Untuk pengguna yang belum login dan pengguna yang telah login tetapi tidak memiliki rekomendasi, modul recommended product menampilkan data buku berdasarkan best seller (Gambar 5).

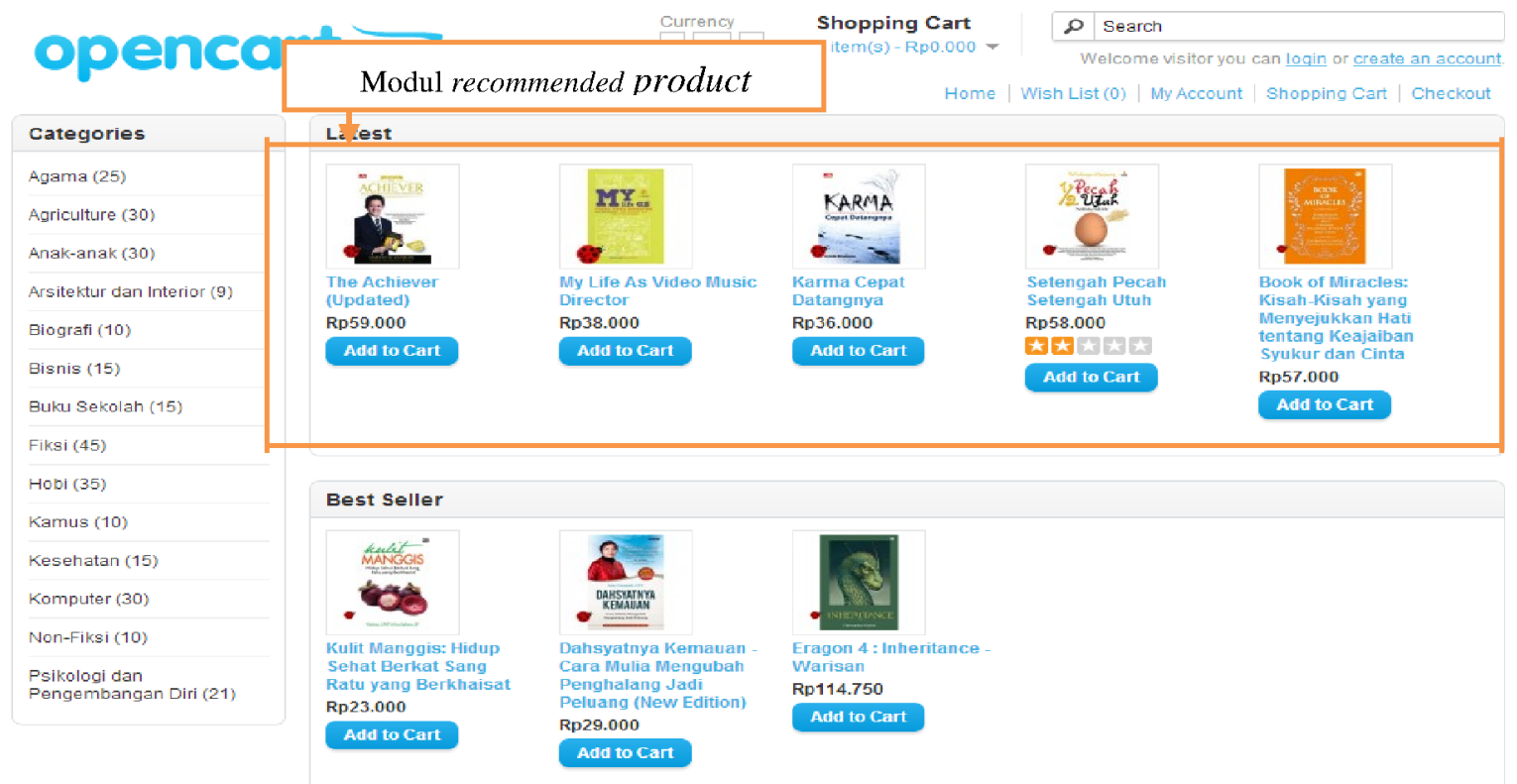

Gambar 5 Halaman home untuk pengguna yang belum login dan pengguna yang telah login tetapi tidak memiliki rekomendasi

Data best seller didapat dari perhitungan pemesanan buku terbanyak yang dilakukan pada sistem. Untuk pengguna yang telah login dan memiliki rekomendasi buku, modul recommended product menampilkan data buku hasil rekomendasi (Gambar 6). 


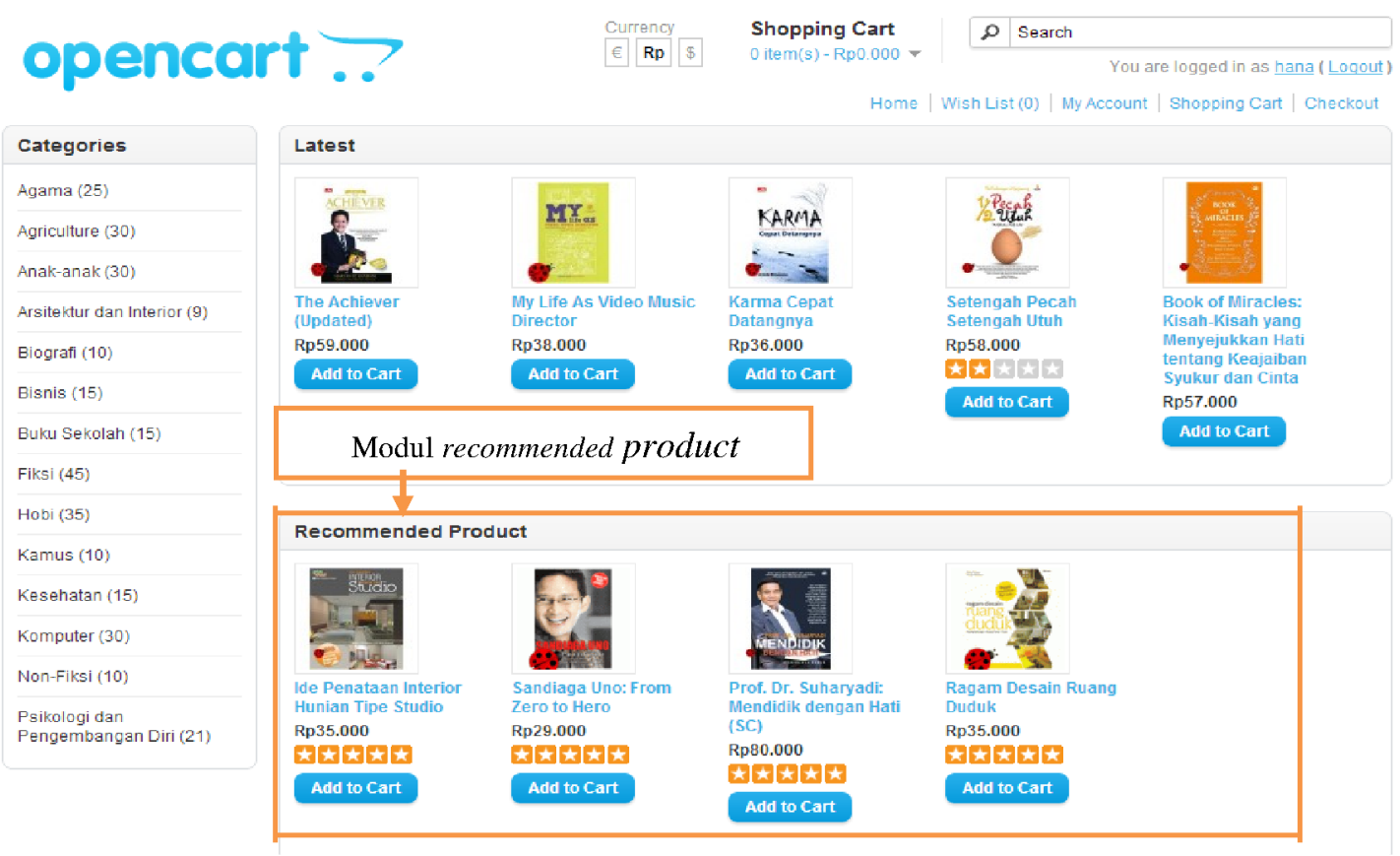

Gambar 6 Halaman home pengguna yang telah login dan memiliki rekomendasi

\section{Implementasi Item-Based Collaborative Filtering}

\section{Adjusted Cosine Similarity}

Adjusted cosine similarity digunakan untuk menghitung nilai kemiripan antarbuku. Data yang diperlukan dalam perhitungan adjusted cosine similarity adalah data rate pengguna dan data rata-rata rate pengguna. Data rate untuk menghitung kemiripan diambil dari tabel review pada database, sedangkan data rata-rata rate dari pengguna diambil dari tabel review_average pada database. Data pada tabel review_average dicari dengan menghitung rata-rata rate dari pengguna, yang dihitung dengan menggunakan query sebagai berikut:

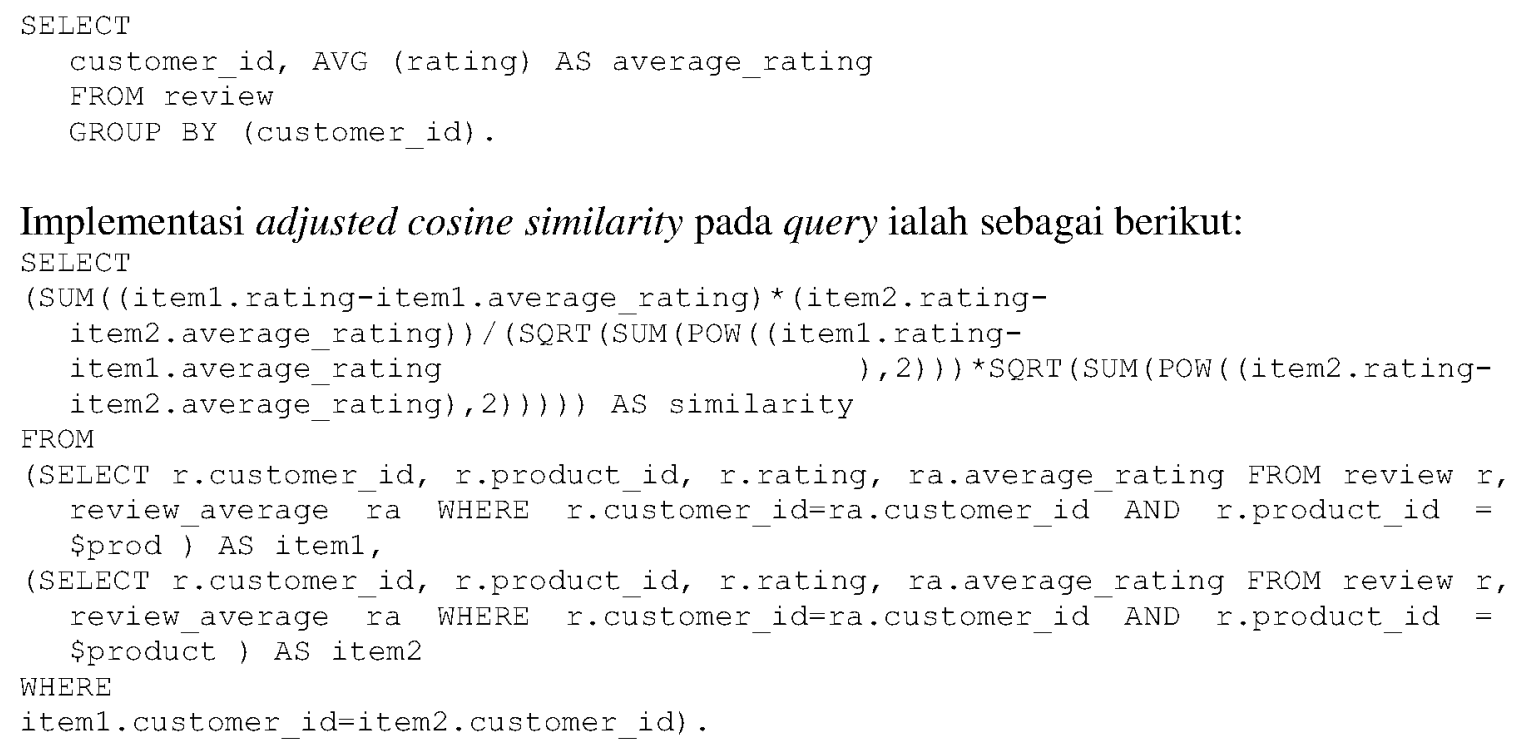

Implementasi adjusted cosine similarity pada query ialah sebagai berikut:

Pada query adjusted cosine similarity, \$prod dan \$product merupakan parameter masukan dari id buku yang telah diberi rate. Nilai kemiripan ini disimpan dalam tabel similarity pada database. Nilai kemiripan yang disimpan dalam database hanya yang memiliki nilai kemiripan lebih besar dari 0.5. Berdasarkan query adjusted cosine similarity, terdapat 93 pasangan buku yang berkorelasi tinggi. Pasangan buku yang berkorelasi tinggi disimpan dalam tabel similarity pada database. Data pada tabel similarity semuanya memiliki 
nilai kemiripan 1.0. Nilai kemiripan yang seragam ini disebabkan oleh: (1) pengguna yang memberi rate pada buku yang berbeda dengan nilai yang sama, dan (2) sebuah buku hanya diberi rate oleh satu atau dua pengguna.

\section{Weighted Sum}

Weighted sum digunakan untuk menghitung nilai prediksi rate buku. Data yang diperlukan dalam perhitungan weighted sum adalah data rate pengguna dan data kemiripan antarbuku yang berkorelasi tinggi. Data rate pengguna diambil dari tabel review dan data kemiripan antarbuku diambil dari tabel similarity. Implementasi weighted sum pada query adalah sebagai berikut:

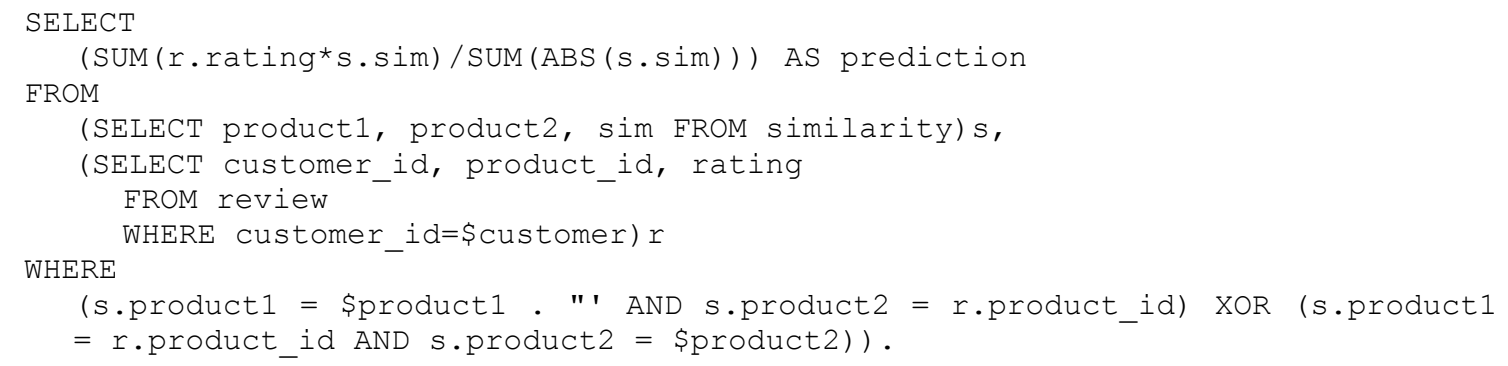

Pada query weighted sum, \$customer merupakan parameter masukan dari customer_id. \$product1, dan \$product2 merupakan masukan dari pasangan buku yang terdapat pada tabel similarity. Berdasarkan query weighted sum terdapat 297 nilai prediksi rate buku. Prediksi yang diberikan kepada pengguna adalah prediksi buku yang belum pernah diberi rate oleh pengguna dan kategorinya sama dengan kategori buku yang pernah diberi rate oleh pengguna yang bersangkutan. Pengguna yang memiliki rekomendasi hanya 17 pengguna, yaitu pengguna dengan customer_id $6,7,8,10,11,15,17,18,20,23,24,25,28,30,31,32$, dan 33 . Beberapa pengguna tidak mendapatkan rekomendasi karena pengguna hanya memberi rate pada kategori tertentu saja atau rate yang diberikan seorang pengguna bertolak belakang dengan rate yang diberikan oleh pengguna lainnya.

\section{Pengujian Item-Based Collaborative Filtering}

\section{Pengujian keakuratan rekomendasi}

Pengujian dilakukan dengan menghitung Mean Absolute Error (MAE) dan waktu eksekusi yang dibutuhkan untuk menjalankan query adjusted cosine similarity dan query weighted sum. Pengujian yang pertama dilakukan adalah melakukan perhitungan MAE dengan membandingkan nilai rate prediksi dan nilai rate yang diberi oleh pengguna. Implementasinya pada query ialah sebagai berikut:

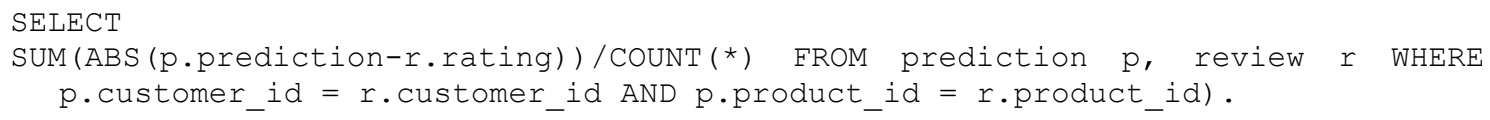

Berdasarkan perhitungan MAE, tingkat kesalahan perhitungan yang dihasilkan relatif kecil, yaitu 0.145. Semakin kecil nilai MAE, semakin akurat rekomendasi yang dihasilkan.

\section{Pengujian waktu eksekusi}

Pengujian yang dilakukan selanjutnya merupakan penghitungan waktu eksekusi untuk menjalankan query persamaan 1 dan 2. Penghitungan waktu eksekusi dilakukan dengan aplikasi tambahan yang terdapat pada web browser, yaitu page load time. Berdasarkan perhitungan page load time, rata-rata waktu eksekusi yang dibutuhkan adalah 60.7 detik. Tingginya waktu eksekusi ini disebabkan oleh proses pembuatan tabel yang cukup lama. Namun, lamanya waktu eksekusi ini tidak mengganggu pengguna karena algoritme diletakkan pada bagian admin sistem. Waktu eksekusi rata-rata dari 30 pengguna adalah 1.57 detik. Waktu eksekusi pada bagian pengguna digunakan untuk membandingkan kategori dari buku 
yang telah diberi rate dan kategori dari prediksi buku. Menurut Miller (1968), respons pengguna terhadap waktu eksekusi halaman dibagi menjadi tiga, yaitu: (i) 0.1 detik yaitu pengguna merasa sistem bekerja sangat cepat, (ii) 1 detik yaitu batas pengguna tidak merasakan adanya gangguan, dan (iii) 10 detik yaitu batas memungkinkan pengguna untuk tetap fokus dan tidak meninggalkan halaman website. Waktu eksekusi untuk menghasilkan rekomendasi pada penelitian ini berada pada bagian ketiga yang masih memungkinkan pengguna untuk tetap fokus dan tidak meninggalkan halaman website.

\section{SIMPULAN}

Metode item-based collaborative filtering telah berhasil diimplementasikan menggunakan CMS OpenCart. Keakuratan metode item-based collaborative filtering dihitung menggunakan persamaan MAE. Tingkat kesalahan hitung metode item-based collaborative filtering pada sistem ini relatif kecil, yaitu 0.15. Semakin kecil nilai MAE, semakin akurat rekomendasi yang dihasilkan. Waktu eksekusi untuk menghasilkan prediksi membutuhkan waktu yang relatif lama, yaitu 61.00 detik. Waktu eksekusi untuk menampilkan rekomendasi pada pengguna relatif cepat dengan rata-rata 1.60 detik.

\section{DAFTAR PUSTAKA}

Balabanovic M, Shoham Y. 1997. Fab: Content-based collaborative recommendation. Communication of the ACM 40(3):66-72.

Burke R. 2002. Hybrid Recommender Systems: survey and experiments. User Modelling and User-Adapted Interactioni. 12(4):331-370.

Candillier L, Meyer F, Boullé M. 2007. Comparing state-of-the-art collaborative filtering systems. Di dalam: International Conference on Machine Learning and Data Mining; 2007 Jul 18-20; Leipzig, Jerman. hlm 548-562.

Goldberg K, Roeder T, Gupta D, Perkins C. 2001. Eigenstate: A constant time collaborative filtering algorithms. Information Retrieval Journal 4:133-151.

Karypis G. 2001. Evaluation of ttem-based top-N recommendation. Di dalam: 10th International Conference of Information and Knowledge Management (CIKM); 2001 Nov 5-10; Atlanta, Amerika Serikat. hlm 247-254.

Marmanis H, Babenko D. 2009. Algorithms of the Intelligent Web. Greenwich(UK): Manning Publ.

Masalov K. 2007. Developing Country E-commerce portal.Honours project report. University of Cape Town.

Miller RB. 1968. Response time in man-computer conversational transactions. Di dalam: Proceedings of AFIPS Fall Joint Computer Conferencel; 1968 Des 9-11; San Fransisco, Amerika Serikat. hlm 267-277.

O'Brien JA. 2006. Introduction to Information System.Ed ke-12. New York(US): McGraw Hill.

Saidah HT. 2012. Kajian Usability website e-commerce Indonesia berdasarkan perspektif tipe pengguna browser dan evaluator [skripsi]. Bogor(ID): Fakultas Matematika dan Ilmu Pengetahuan Alam, Institut Pertanian Bogor

Sarwar B, Karypis G, Konstan JA, Riedl J. 2001. Item-based collaborative filtering recommendation algorithms. Di dalam: Proceedings of the $10^{\text {th }}$ International World Wide Web Conference; 2001 Mei 1-5; Hong Kong. hlm 285-295. 